\title{
Influence of pH on the Growth, Laccase Activity and RBBR Decolorization by Tropical Basidiomycetes
}

\author{
Sérgio Luiz Moreira Neto ${ }^{1}$, Dácio Roberto Matheus ${ }^{2}$ and Kátia Maria Gomes Machado ${ }^{1^{*}}$ \\ ${ }^{1}$ Departamento de Ciências Biológicas; Universidade Católica de Santos; Santos - SP - Brasil. ${ }^{2}$ Instituto de \\ Botânica; São Paulo - SP - Brasil
}

\begin{abstract}
The basidiomycete fungi Lentinus crinitus and Psilocybe castanella are being evaluated in a bioremediation process of soils contaminated with organochlorine industrial residues in the Baixada Santista, São Paulo. The aim of the present study was to determine the influence of $\mathrm{pH}$ on the fungal growth, in vitro decolorization of anthraquinonic dye Remazol Brilliant Blue $R(R B B R)$ and laccase activity. The pH of the culture medium influenced the growth of L. crinitus and P. castanella, which presented less growth at pH 5.9 and pH 2.7, respectively. The fungi were able to modify the $\mathrm{pH}$ of the culture medium, adjusting it to the optimum $\mathrm{pH}$ for growth which was close to 4.5. Decolorization of the RBBR was maximal at a pH of 2.5 to 3.5. Higher laccase activity was observed at $\mathrm{pH} 3.5$ and $\mathrm{pH} 4.5$ for L. crinitus and $\mathrm{P}$. castanella, respectively. $\mathrm{pH}$ was found to be an important parameter for both the growth of these fungi and the enzymatic system involved in RBBR decolorization.
\end{abstract}

Key words: White rot fungi, RBBR, laccase, peroxidases

\section{INTRODUCTION}

A series of studies have been conducted with the objective to reduce the level of pollution of organochlorine contaminated soils by the application of Brazillian basidiomycete fungi (Matheus et al., 2000, 2001; Machado et al., 2005). The metabolism of polluting compounds by basidiomycetes seems to be the consequence of the mechanism used by these organisms to degrade the lignin. The degradation of lignin by these fungi is an oxidative, extracellular and nonspecific process which is the result of the coordinated action of a series of intra- and extracellular enzymes (peroxidases, laccases and hydrogen peroxideproducing oxidases) and low molecular mass metabolites (Tortella et al., 2005; Baldrian, 2006; Husain, 2006).
The ability of Lentinus crinitus CCB274 and Psilocybe castanella CCB444 to degrade hexachlorobenzene has been studied in bioreactors with a capacity of $400 \mathrm{Kg}$ soil (Fig. 1). The growth of these fungi in the bioreactor has been accompanied for 70 to 100 days and different parameters such as temperature, $\mathrm{pH}$, humidity, organic carbon, biomass and ligninolytic enzymes have been monitored. Over time, a reduction in soil $\mathrm{pH}$ was observed during the growth of the fungi. In the bioreactor containing L crinitus, the initial $\mathrm{pH}$ of 6.67 decreased to 2.87 after 21 days of incubation, stabilizing at 3.84 at the end of 73 days. In the bioreactor inoculated with $P$. castanella, the $\mathrm{pH}$ ranged from 4.60 to 3.60 within the same period of time (Matheus et al., 2003).

In general, fungi grow over a wide $\mathrm{pH}$ range, with the optimum $\mathrm{pH}$ being situated in the acid range

\footnotetext{
* Author for correspondence: katia@unisantos.br
} 
for most of them. In these organisms, the $\mathrm{pH}$ does not only affect the growth but also the production and activity of metabolites due to the effect of $\mathrm{pH}$ on cell permeability and the availability of certain metals such as magnesium, phosphorus, iron, calcium, and zinc. The influence of $\mathrm{pH}$ on the growth, production and activity of ligninolytic enzymes, and the degradation of aromatic compounds such as lignin and environmental pollutants by basidiomycetes have been the subject of several studies (Galhaup et al., 2002; Lechner and Pappinutti, 2006; Zouari-Mechichi et al., 2006).

The objective of the present investigation was to determine the influence of $\mathrm{pH}$ on the growth of $P$. castanella and $L$. crinitus and the effect of reaction $\mathrm{pH}$ on ligninolytic activities and decolorization of RBBR by enzymatic extract in order to optimize their application in the bioremediation process of soils.

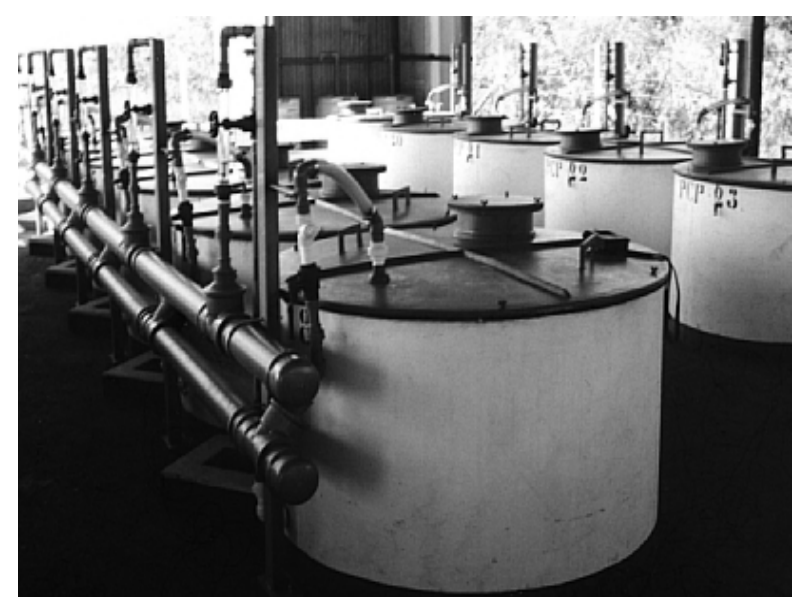

Figure 1 - Bioreactors with a capacity of $400 \mathrm{~kg}$ soil used for fungal culture, São Vicente, SP (Photo: Ricardo R. da Silva, 2004).

\section{MATERIAL AND METHODS}

\section{Fungi}

Lentinus crinitus CCB274 and Psilocybe castanella CCB444 were provided by the Basidiomycete Culture Collection (CCB) of the Institute of Botany, SMA, São Paulo, and were maintained by successive replating on $2 \%$ malt extract agar (MEA) (1\% glucose, $0.1 \%$ peptone, $1 \%$ malt extract and $1.8 \%$ agar) at $4^{\circ} \mathrm{C}$.

\section{Culture conditions}

The fungi were grown in $2 \%$ malt extract broth (MEB) whose composition was the same as that of MEA without the addition of agar. The $\mathrm{pH}$ of the medium was adjusted with $0.1 \mathrm{M} \mathrm{NaOH}$ and 0.1 $\mathrm{M} \mathrm{H}_{2} \mathrm{SO}_{4}$ before sterilization $\left(121^{\circ} \mathrm{C}, 15 \mathrm{~min}\right)$ to 2.5, 4.5, 5.5 and 6.0. Two 5-mm fungal MEA discs (5 to 7 days) were inoculated into $250-\mathrm{mL}$ flasks containing $30 \mathrm{~mL}$ MEB. The cultures were incubated at room temperature in a stationary manner. At given time intervals, the content of the flasks was filtered through filter paper and the biomass was determined as dry weight $\left(80^{\circ} \mathrm{C}\right.$ for $24 \mathrm{~h})$. The filtrate was used for the determination of $\mathrm{pH}$ and decolorization of the anthraquinone dye Remazol Brilliant Blue R (RBBR). The experiments were carried out in duplicate.

\section{In vitro decolorization of $\mathrm{RBBR}$}

Decolorization of RBBR was assayed by the decrease in absorbance at $585 \mathrm{~nm}$ as described by Machado and Matheus (2006). The reaction mixture contained $5.0 \mathrm{~mL}$ of the enzymatic extract, $100 \mu \mathrm{L}$ distilled water and $50 \mu \mathrm{L} 2 \%$ RBBR solution. After $1 \mathrm{~h}$, absorbance was read in samples diluted 1:10 in distilled water. One unit of decolorization was defined as the amount able to catalyze a reduction of 0.01 in absorbance compared to a control prepared with previously heat-inactivated enzymatic extract (10 min).

\section{Effect of reaction $\mathrm{pH}$ on ligninolytic activities}

$P$. castanella and L. crinitus were grown stationary in MEB at an initial $\mathrm{pH}$ of 4.5 for 14 days at room temperature. The content of the flasks was filtered 
and the $\mathrm{pH}$ of the filtrate was adjusted to $2.5,3.5$ and 4.5. These filtrates were used for the determination of the peroxidase and laccase activities involved in the decolorization of RBBR and in the oxidation of ABTS.

\section{In vitro decolorization of $\mathrm{RBBR}$ by peroxidases}

The peroxidase activity involved in the decolorization of RBBR was determined using the same method as employed for the in vitro decolorization of RBBR replacing distilled water with $2 \mathrm{mM}$ hydrogen peroxide.

\section{In vitro decolorization of $\mathrm{RBBR}$ by laccase}

The laccase activity involved in the decolorization of RBBR was determined by the same method as employed for the in vitro decolorization of RBBR using enzymatic extract previously incubated with $100 \mu \mathrm{L}$ catalase (Sigma, $1000 \mathrm{mU} / \mathrm{L}$ ) for $10 \mathrm{~min}$.

\section{Peroxidase and laccase activities}

Oxidation of 2,2'-azino-bis(3-ethylbenzthiazoline6-sulphonic acid) (ABTS) by peroxidases was monitored at $420 \mathrm{~nm}\left(\varepsilon=36,000 \mathrm{M}^{-1} \mathrm{~cm}^{-1}\right)$. The reaction mixture contained (in $1 \mathrm{~mL}$ ) $800 \mu \mathrm{L}$ of the enzymatic extract, $100 \mu \mathrm{L} 2 \mathrm{mM}$ hydrogen peroxide and $100 \mu \mathrm{L} 1 \mathrm{mM}$ ABTS (Bourbonnais and Paice, 1988). Oxidation of ABTS by laccase was assayed using an enzymatic extract previously incubated with $100 \mu \mathrm{L}$ catalase for $10 \mathrm{~min}$. One enzymatic unit corresponded to the amount of enzyme able to oxidize $1 \mu \mathrm{mol}$ of the substrate per minute.

\section{RESULTS AND DISCUSSION}

The $\mathrm{pH}$ of the culture medium influenced the growth of the basidiomycetes $L$. crinitus and $P$. castanella, which presented less growth at $\mathrm{pH} 5.9$ (Fig. 2) and $\mathrm{pH} 2.7$ (Fig. 3), respectively. The fungi altered the initial $\mathrm{pH}$ of the medium. During the growth of $L$. crinitus in medium with an initial $\mathrm{pH}$ of 2.5 , the $\mathrm{pH}$ evolution during the cultivation tended to increase, reaching a value close to $\mathrm{pH}$ 4.0 at 14 days. In the other medium, the $\mathrm{pH}$ stabilized at about 4.5 by day 7 of incubation (Fig. 2). A similar behavior was observed during the growth of $P$. castanella; however, in medium with an initial $\mathrm{pH}$ higher than 4.0, the $\mathrm{pH}$ evolution did not stabilize during the incubation period (Fig. 3) Most biochemical studies on the degradation of polluting compounds have used the white rot fungus Phanerochaete chrysosporium as a model system. This fungus possesses an optimum $\mathrm{pH}$ for growth close to 4.5 (Kirk et al., 1978). The optimum $\mathrm{pH}$ for growth of other basidiomycete fungi such as Polyporus sanguineus and Trametes pubescens is also found in this $\mathrm{pH}$ range (Sandhu and Arora, 1985; Galhaup et al., 2002). The present results demonstrated that the optimum $\mathrm{pH}$ for the growth of $L$. crinitus and P. castanella was also close to 4.5. Acidification of the culture medium during the fungal growth has been related to the production of organic acids (Makela et al., 2002; Aguiar et al., 2006). Tekere and co-workers (2001) observed alterations in the initial $\mathrm{pH}$ values of the culture medium during the growth of various basidiomycete species: the $\mathrm{pH}$ tended to increase when the initial $\mathrm{pH}$ was less than 4.0 and the opposite was observed when the initial $\mathrm{pH}$ was higher than 4.5. A reduction of the initial $\mathrm{pH}$ of the culture medium from 5.0 to 3.6 was also observed during the growth phase (first 12 days) of Trametes pubescens (Galhaup et al., 2002). Rigas and Dritsa (2006) observed redution of the $\mathrm{pH}$ from 6.7 to 4-5 during the growth of Ganoderma australe, Polyporus brumalis and P. ciliatus.

The use of dyes as model compounds in pollutant biodegradation studies offers a series of advantages compared to conventional substrates: dyes are stable, soluble, possess high molar extinction coefficients and low toxicity, and can be applied in simple, rapid and quantitative spectrophotometric assays. RBBR has been widely used since, as an anthracene derivative, this compound represents an important group of organopollutants (Novotny et al., 2004; Deveci et al., 2004). In the present study, the initial pH of the culture medium influenced the in vitro decolorization of RBBR by the fungi studied. Maximum decolorization of RBBR by the enzymatic extract of $L$. crinitus was observed at 14 days in medium with an initial pH of 4.5 (Fig. 2). Maximum decolorization of RBBR by the enzymatic extract of $P$. castanella was also observed after 14 days, but at an initial $\mathrm{pH}$ of the medium of 5.9 (Fig. 3). The optimum $\mathrm{pH}$ for the decolorization of the dye Poly R478 ranged from 3 to 5 for Trametes pocas, T. cingulata, Pycnoporus sanguineus and Datronia concentrica (Tekere et al., 2001).

The production of organic acid by $L$. crinitus and $P$. castanella, which reduces the $\mathrm{pH}$ of the culture 
medium, might have stimulated the decolorization of RBBR. The role of organic acids in the degradation of aromatic compounds catalyzed by ligninolytic enzymes (peroxidases and laccase) has been well documented in the literature. The organic acid- $\mathrm{Mn}^{3+}$ complex acts as a strong redox mediator which is able to attack lignin structures, forming unstable free radicals that tend to disintegrate spontaneously (Hofrichter et al., 1999, Tekere et al., 2001; Hofrichter, 2002; Makela et al., 2002).

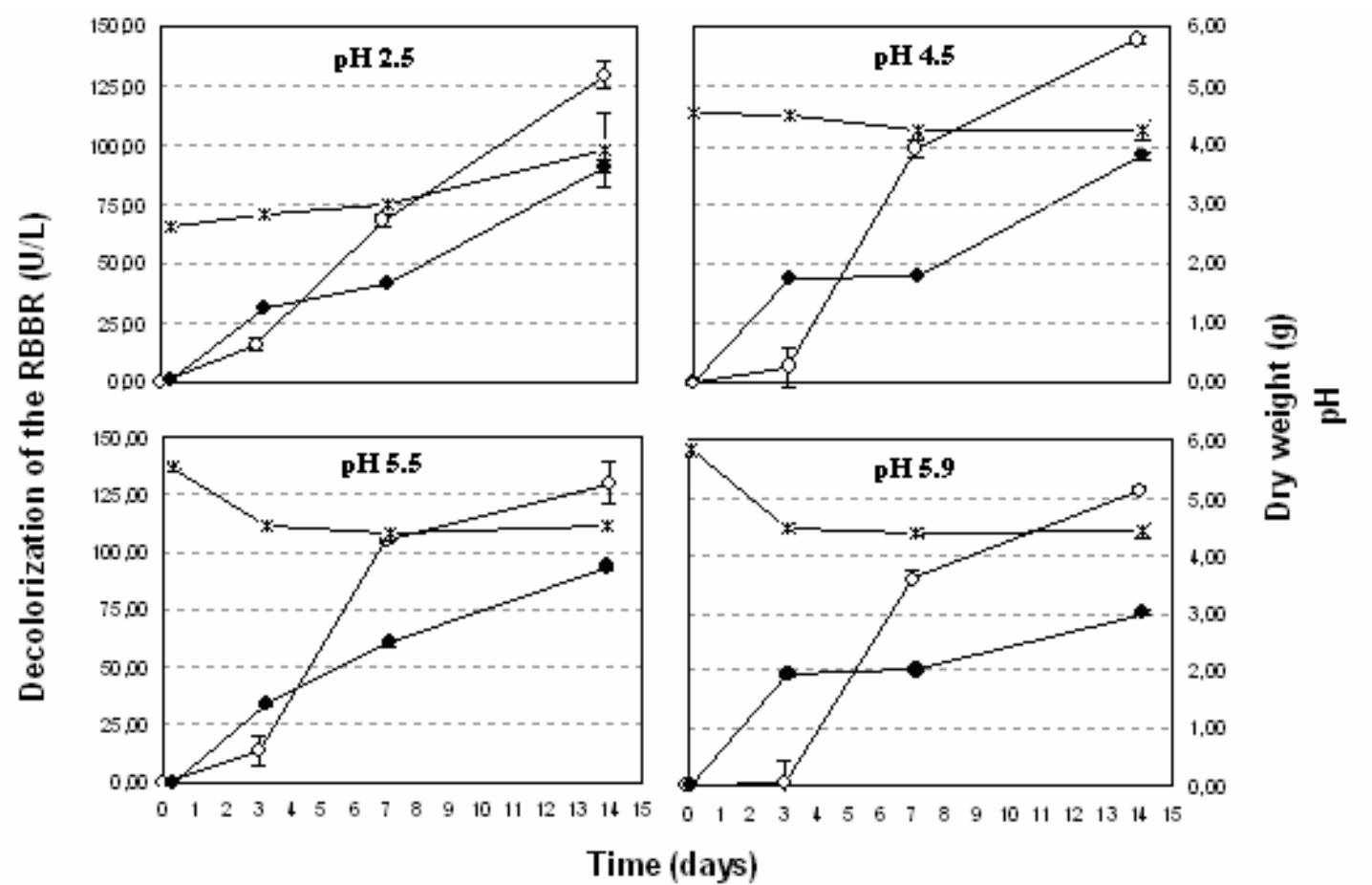

Figure 2 - Decolorization of the dye Remazol R Brilliant Blue (RBBR) by the enzymes extracted from Lentinus crinitus CCB274 grown at room temperature at different $\mathrm{pH}$ values. (O) Decolorization of RBBR; (๑) dry weight; (Ж) $\mathrm{pH}$ evolution of the culture medium. The bars indicate the standard deviation between duplicate measurements.

The $\mathrm{pH}$ of the reaction influenced the activity of ligninolytic enzymes produced by the basidiomycetes and involved in the in vitro decolorization of RBBR. For $L$. crinitus, the optimum $\mathrm{pH}$ for $\mathrm{RBBR}$ decolorization ranged from 2.5 to 3.5 (Fig. 4). In contrast, for $P$. castanella, the optimum $\mathrm{pH}$ for in vitro $\mathrm{RBBR}$ decolorization was 3.5. The same $\mathrm{pH}$ profile was observed for the peroxidase and laccase activities produced by $L$. crinitus and $P$. castanella involved in the decolorization of RBBR. This finding demonstrated the capacity of the enzymatic extracts of these fungi to decolorize RBBR without the addition of hydrogen peroxide, indicating the action of laccase-type oxidases in this process. The identity of the enzymes involved in the degradation of RBBR has not been completely established but degradation is believed to result from the coordinated action of peroxidases and hydrogen peroxide-producing oxidases (Soares et al., 2001; Shin 2004). Recent studies also indicated the involvement of laccases alone or in the presence of specific mediators (Baldrian, 2004; Champagne and Ramsay, 2005; Lu et al., 2007; Murugesan et al., 2007). 


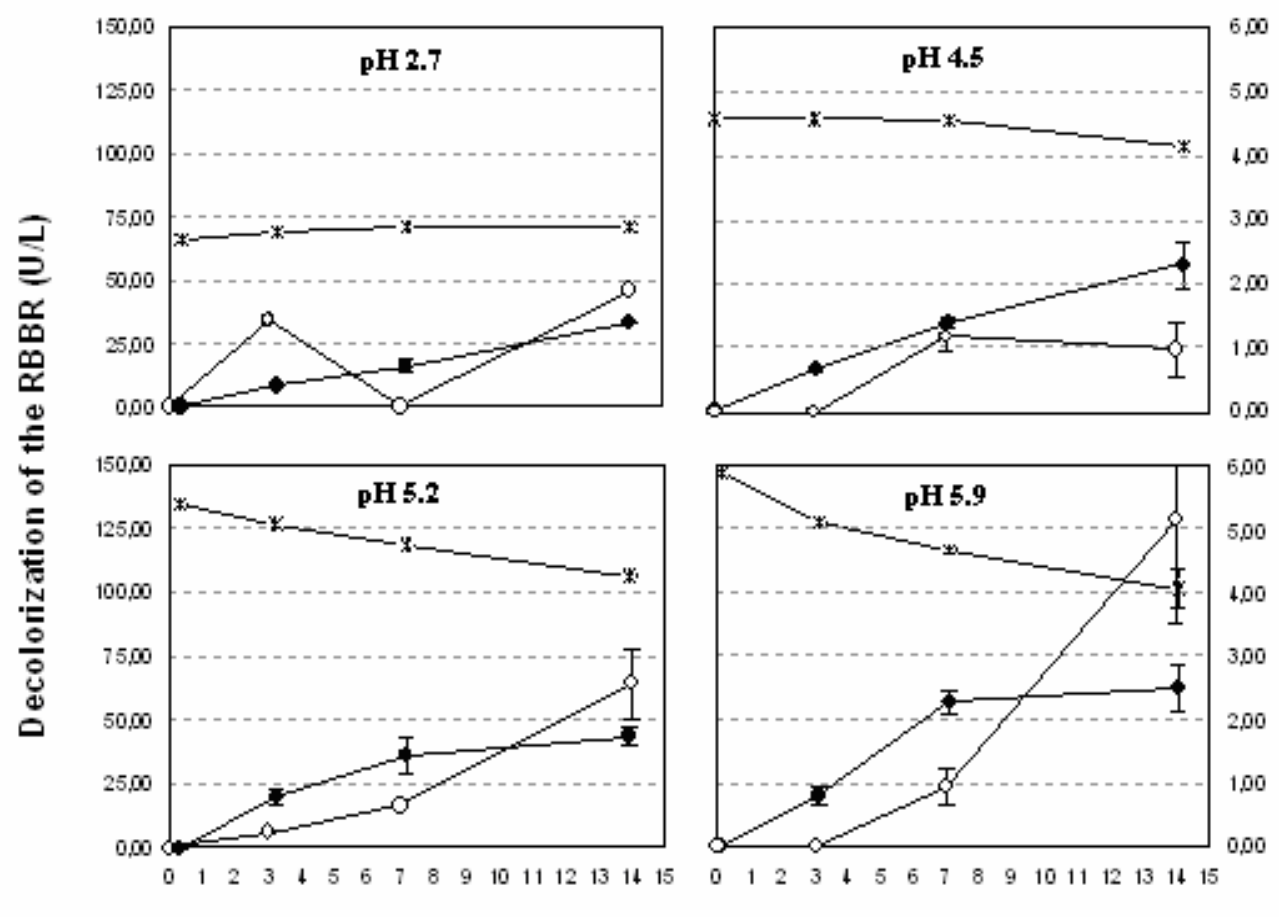

Figure 3 - Decolorization of the dye Remazol R Brilliant Blue (RBBR) by the enzymes extracted from Psilocybe castanella CCB444 grown at room temperature at different $\mathrm{pH}$ values. (○) Decolorization of RBBR; (๑) dry weight; (Ж) $\mathrm{pH}$ evolution of the culture medium. The bars indicate the standard deviation between duplicate measurements.

The peroxidase and laccase activities produced by $L$. crinitus and $P$. castanella, which oxidized ABTS, presented the same $\mathrm{pH}$ profile, with a predominance of laccase being observed in the enzymatic extracts of these fungi (Fig. 5). For $L$. crinitus, the highest laccase activity was obtained at $\mathrm{pH} 3.5(35.0 \mathrm{U} / \mathrm{L})$, whereas for $P$. castanella maximum activity was observed at $\mathrm{pH} 4.5$ (19.5 $\mathrm{U} / \mathrm{L})$. These results demonstrated differences in the $\mathrm{pH}$ optimum between the laccases produced by these fungi. The optimum $\mathrm{pH}$ for laccase activity vary for each fungal strain, such as observed in $P$. castanella and L. crinitus laccases from other basidiomycetes presented optimum $\mathrm{pH} 3.0$ using ABTS as substrate (Saparrat et al., 2002; Ryan et al., 2003; Zouari-Mechichi et al., 2006).

The present results demonstrated that i) the $\mathrm{pH}$ of the culture medium influenced the growth and in vitro decolorization of RBBR by $L$. crinitus CCB274 and P. castanella CCB444; ii) the fungi were able to alter the initial $\mathrm{pH}$ of the medium so that it would reach the optimum $\mathrm{pH}$ for growth; iii) RBBR decolorization by these fungi seemed to be the result of the action of laccase-type oxidases. 


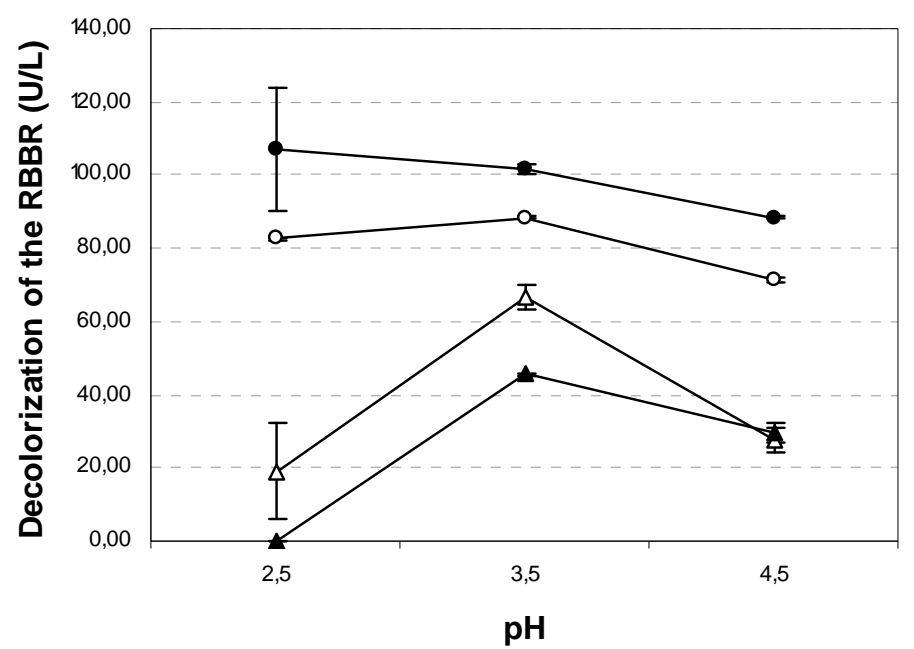

Figure 4 - Effect of $\mathrm{pH}$ of the reaction on the ligninolytic enzymatic activity involved in the decolorization in vitro of the dye Remazol R Brilliant Blue (RBBR) produced by Lentinus crinitus CCB274 ( $\circ$, peroxidases; $\bullet$, laccase) and Psilocybe castanella CCB444 $(\Delta$, peroxidases; $\boldsymbol{\Lambda}$, laccase) during growth in malt extract broth at room temperature. The bars indicate the standard deviation between duplicate measurements.

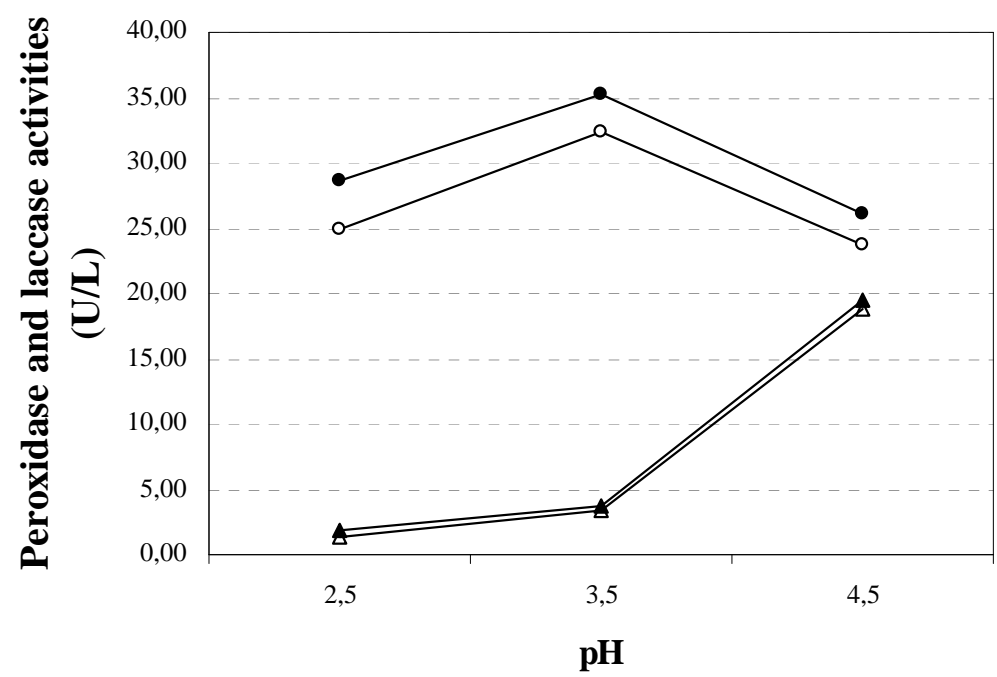

Figure 5 - Effect of $\mathrm{pH}$ of the reaction on the ligninolytic enzymatic activity involved in the oxidation of ABTS produced by Lentinus crinitus CCB274 ( $\circ$, peroxidases; • laccase) and Psilocybe castanella $\mathrm{CCB} 444$ ( $\Delta$, peroxidases; $\boldsymbol{\Delta}$, laccase) during growth in malt extract broth at room temperature. 


\section{ACKNOWLEDGMENTS}

We thank Universidade Católica de Santos and Fundação para o Desenvolvimento da Pesquisa Agropecuária.

\section{RESUMO}

Os fungos basidiomicetos Lentinus crinitus e Psilocybe castanella estão sendo avaliados em processo de biorremediação de solos contaminados com resíduos industriais organoclorados, na Baixada Santista, SP. O presente estudo avaliou a influência do $\mathrm{pH}$ no crescimento, na descoloração in vitro do corante Azul Brilhante de Remazol R (RBBR) e na atividade de lacase durante cultivo destes fungos, de forma a subsidiar a otimização do processo. $\mathrm{O}$ $\mathrm{pH}$ do meio influenciou o crescimento de $L$. crinitus e de $P$. castanella, com menor biomassa

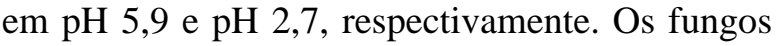
foram capazes de modificar o $\mathrm{pH}$ inicial do meio de cultura, de modo a ajustá-lo ao valor ótimo de crescimento, próximo a 4,5. Descoloração in vitro do RBBR foi máxima em $\mathrm{pH}$ 2,5 e 3,5. Maiores atividades de lacase foram obtidas em $\mathrm{pH} \mathrm{3,5} \mathrm{e}$ em $\mathrm{pH}$ 4,5 para L. crinitus e $P$. castanella, respectivamente. Evidenciou-se que o $\mathrm{pH}$ é um parâmetro importante para o crescimento destes fungos, atividade de lacase e descoloração in vitro do RBBR.

\section{REFERENCES}

Aguiar, A.; Souza-Cruz, P. B. and Ferraz, A. (2006), Oxalic acid, $\mathrm{Fe}^{3+}$-reduction activity and oxidative enzymes detected in culture extracts recovered from Pinus taeda wood chips biotreated by Ceriporiopsis subvermispora. Enzyme and Microbial Technology, 38, 873-878.

Baldrian, P. (2004), Purification and characterization of laccase from the white-rot fungus Daedalea quercina and decolorization of synthetic dyes by the enzyme. Applied Microbiology Biotechnology, 63, 560-563.

Baldrian, P. (2006), Fungal laccases - occurrence and properties. FEMS Microbiology Reviews, 30 (2), 215242.
Champagne, P. P. and Ramsay, J. A. (2005), Contribution of manganese peroxidase and laccase to dye decoloration by Trametes versicolor. Applied Microbiology Biotechnology, 69 (3), 276-285.

Bourbonnais, R. and Paice, M. G. (1988), Veratryl alcohol oxidases from the lignin-degrading basidiomycete Pleurotus sajor-caju. Biochemical Journal, 255, 445-450.

Deveci, T.; Unyayar, A. and Mazmanci, M. A. (2004), Production of Remazol Brilliant Blue R decolourising oxygenase from the culture filtrate of Funalia trogii ATCC 200800. Journal of Molecular Catalysis B: Enzymatic, 30, 25-32.

Galhaup, C.; Wagner, H.; Hinterstoisser, B. and Haltrich, D. (2002), Increased production of laccase by the wood-degrading basidiomycete Trametes pubescens. Enzyme and Microbial Technology, 30, 529-536.

Hofrichter, M. (2002), Review: lignin conversion by manganese peroxidase (MnP). Enzyme and Microbial Technology, 30, 454-466.

Hofrichter, M.; Vares, T.; Kalsi, M.; Galkin, S.; Scheibner, K.; Fritsche, W. and Hatakka, A. (1999), Production of manganese peroxidase and organic acids and mineralization of $14 \mathrm{C}$ - Labelled lignin (14C-DHP) during white rot fungus Nematoloma frowardii. Applied and Environmental Microbiology, 65: (5), 1864-1870.

Husain, Q. (2006), Potential Applications of the Oxidoreductive Enzymes in the Decolorization and Detoxification of Textile and Other Synthetic Dyes from Polluted Water: A Review. Critical Reviews in Biotechnology, 26 (4), 201-221.

Kirk, T. K.; Schultz, E.; Connors, W. J.; Lorenz, L. F. and Zeikus, J. G. (1978), Influence of Culture Parameters on Lignin Metabolism by Phanerochaete chrysosporium. Archives of Microbiology, 117, 277285.

Lechner, B. E. and Papinutti, V. L. (2006), Production of lignocellulosic enzymes during growth and fruiting of the edible fungus Lentinus tigrinus on wheat straw. Process Biochemistry, 41, 594-598.

Lu, L.; Zhao, M.; Zhang, B. B.; Yu, S. Y.; Bian, X. J.; Wang, W. and Wang, Y. (2007), Purification and characterization of laccase from Pycnoporus sanguineus and decolorization of an anthraquinone dye by the enzyme. Applied Microbiology and Biotechnology, 74 (6), 1232-1239.

Machado, K. M. G. and Matheus, D. R. (2006), Biodegradation of Remazol brilliant blue $\mathrm{R}$ by ligninolytic enzymatic complex produced by Pleurotus ostreatus. Brazilian Journal of Microbiology, ISSN/ISBN: 1517382. 
Machado, K. M. G.; Matheus, D. R. and Bononi, V. L. R. (2005), Biodegradation of pentachlorophenol by tropical basidiomicetes in soil contaminated with industrial resides. World Journal of Microbiology and Biotecnology, 21, 297-301.

Makela, M.; Galkin, S.; Hatakka, A. and Lundell, T. (2002), Production of organic acids and oxalate decarboxylase in lignin-degrading white rot fungi. Enzyme and Microbial Technology, 30, 542-549.

Matheus, D. R.; Bononi, V. L. R. and Machado, K. M. G. (2000), Biodegradation of hexachlorobenzene by basidiomycetes in soil contaminated with industrial residues. World Journal of Microbiology and Biotecnology, 16, 415-421.

Matheus, D. R.; Bononi, V. L. R. and Machado, K. M. G. (2001), New basidiomycetes on bioremediation of organochlorine contaminated soil,. In- Bioremediation of Energetics, Phenolics, and Polycyclic Aromatic Hydrocarbons, eds. V. S. M Glenn; J. S. K. Ong, and A. Leeson. Battelle Press, San Diego, pp.99-106.

Matheus, D. R.; Bononi, V. L. R.; Machado, K. M. G.; Silva, R. R. and Rodrigues, T. A. (2003), Growing basidiomycetes in bioreactors to be applied to bioremediation of HCB in soil. Proceedings of the Seventh International In Situ and On-Site Bioremediation Symposium. In: Magar, V. S. and Kelley, M. E. (Eds.). In Situ and On-Site Bioremediation, Battelle Press, Columbus, p. G-05.

Murugesan, K.; Arulmani, M.; Nam, I. H.; Kim, Y. M.; Chang, Y. S.; Kalaichelvan, P. T. (2007), Purification and characterization of laccase produced by a white rot fungus Pleurotus sajor-caju under submerged culture condition and its potential in decolorization of azo dyes. Applied Microbiology and Biotechnolology, 40 (7), 1662-1672.

Novotny, C.; Svobodová, K.; Erbanová, P.; Cajthaml, T.; Kasinath, A.; Lang, E. and Sasek, V. (2004), Ligninolytic fungi in bioremediation: extracellular enzyme production and degradation rate. Soil Biology and Biochemistry, 36, 1545-1551.

Rigas, F. and Dritsa, V. (2006), Decolourisation of a polymeric dye by selected fungal strains in liquid cultures. Enzyme and Microbial Technology, 39, 120124.
Ryan, S.; Schnitzhofer, W.; Tzanov, T.; Cavaco-Paulo, A. and Gübitz, G. M. (2003), An acid-stable laccase from Sclerotium rolfsii with potential for wool dye decolourization. Enzyme and Microbial Technology, 33, 766-774.

Sandhu, D. K. and Arora, D. S. (1984), Lacase production by Polyporus sanguineus under different nutritional and environmental conditions. Birkhäuser Verlag Basel, 41, 355-356.

Saparrat, M.; Guillén, F.; Arambarri, A. M.; Martinez, A. T. and Martinez, M. J. (2002), Induction, Isolation, and Characterization of Two Laccases from the White Rot Basidiomycete Coriolopsis rigida. Applied and Environmental Microbiology, 68 (4), 1534-1540.

Shin, K.-S. (2004), The Role of Enzymes Produced by White-Rot Fungus Irpex lacteus in the Decolorization of the Textile Industry Effluent. The Journal of Microbiology, 42 (1), 37-41.

Soares, G. M. B.; Amorim, M. T. P. and Costa-Ferreira, M. (2001), Use of laccase together with redox mediators to decolourize Remazol Brilliant Blue R. Journal of Biotecnology, 89, 123-129.

Tekere, M.; Mswaka, A.; Zvauya, Y. R. and Read, J. S. (2001), Growth, dye degradation and ligninolytic activity studies on Zimbabwean white rot fungi. Enzyme and Microbial Technology, 28, 420-426.

Tortella, G. R.; Diez, M. C. and Durán, N. (2005), Fungal Diversity and Use in Decomposition of Environmental Pollutants. Critical Reviews in Microbiology, 31, 197-212.

Zouari-Mechichi, H.; Mechichi, T.; Dhouib, A.; Sayadi, S.; Martínez, A. and Martínez, M. (2006), Laccase purification and characterization from Trametes trogii isolated in Tunisia: decolorization of textile dyes by the purified enzyme. Enzyme and Microbial Technology, 39, 141-148.
Received: August 10, 2006; Revised: August 28, 2007; Accepted: November 28, 2008. 